\title{
Epiphytic microbiota of apple in integrated and organic growing
}

\author{
Pintér, Sz. ${ }^{1}$, Beczner, J. ${ }^{1}$, Szabó, Z. ${ }^{2} \&$ Nyéki, J. ${ }^{2}$ \\ ${ }^{1}$ Central Food Research Institute, Department of Food Safety, Unit of Microbiology, Budapest, Hungary \\ ${ }^{2}$ University of Debrecen, Institute for Research and Development, Debrecen, Hungary
}

\begin{abstract}
Summary: The surface microbial contamination is of great interest in case of fruits, since they are they potential sources of spoilage or foodborne diseases. The aim of this work was to compare the epiphytic microbiota of food safety concern of different apple cultivars as a function of cultivation methods (organic versus integrated), production year and place. Investigating 47 samples it was found that the average microbial contamination of the apple surfaces was within a certain range,, practically independent of cultivar, growing area and year. The frequency distribution of the surface bacterial, mould and yeast counts did not show significant differences between growing technologies or varieties. The principal component analysis the samples ranked the apple samples into seven groups on the basis of their microbial contamination level, and the discriminant analysis proved the goodness of grouping. The grouping was independent from cultivars and growing methods. No foodborne pathogen Salmonella spp. and Listeria spp. were found on the surfaces of apples.
\end{abstract}

Key words: apple cultivars, microbiological surface contamination, aerobic total counts, moulds, yeasts, organic growing, integral growing

\section{Introduction}

Fresh fruits and vegetables are essential components of the human diet, and there is a considerable evidence of the health and nutritional benefits associated with their consumption. Significant rise in the consumption trends of fresh produce are noticed recently partly due to the changing lifestyles, partly as a result of worldwide campaigns on healthy nutrition. As a result, an increase in the popularity of fresh, and also the consumption of the minimally-processed ready-to-eat convenience foods increased (Abadias, 2008; $F A O \& W H O, 2008)$. Exotic, import fresh fruits and vegetables appear on the market, and also the choice of minimally-processed, convenience foods (fresh-cut vegetable and fruit salads with or without packaging) broaden. The elongated food chain, as a result of globality in itself result in microbiological problems, partly as spoilage of the product (qualitative and quantitative losses), partly food safety aspects arise. The growers, producers, handlers and distributors are facing different and altering conditions like weather, pests, market value, trends, and customer requests. Changes in growing and logistic practices may influence microbiological food safety.

More attention is paid to the food-borne outbreaks in the last decades related to the consumption of contaminated plant foods. Fresh produce can be a vehicle of bacterial, parasitic and viral pathogens causing human illnesses. Fresh apple is generally not considered as source of food-borne illnesses, and the presence of mycotoxin patulin is of the main concern in apple juices. However, in some cases foodborne outbreaks due to E. coli $\mathrm{O} 157: \mathrm{H7}$, Salmonella spp. were recorded in association with the consumption of unpasteurized apple cider (Lund \& Snowdon, 2000, Zhao, 2005).

The sources of potential contamination of fruits during production are the irrigation water (surface waters), soil, compost and manure, sewage/sludge (Beuchat, 1996, Beuchat \& Ryu, 1997). Survival of bacteria in the soil is influenced by a number of factors (temperature, moisture content, sunlight, $\mathrm{pH}$, available nutrients, etc.) being the temperature the most important parameter - the bacterial survival increases with decreasing temperature. It was also found, that the majority of pathogens in manures applied to land declines below detectable level after 3 months, and the limiting factor of survival is possibly the temperature (Tyrrel \& Quinton, 2003). Nevertheless, survival of Listeria sp. over 6 months (Nicholson et al., 2005), E. coli O 157 over a year (Kudva et al., 1998), and that of Salmonella sp. over 1-2 years (Nicholson et al., 2005) was noticed in soils amended with manure. Increased number of bacteria and moulds was found in soils treated with treated municipal sewage sludge in different type of soils, owing partly due to the carry-over of microbes, but the effect of increased nutrients on the growth of microbes should also be considered (Beczner et al., 2004; Biró et al., 2008).

The main vectors of contamination are the water (rain, irrigation water spreading soil or slurry particles with the attached microbes onto the surface of plants, fruits), animals (insects, birds, rodents), and humans while harvesting, handling and processing (Beuchat, 1996, Tyrrel \& Quinton, 2003, Zhao, 2005). Association of Salmonella contamination with bacterial soft rot of fresh fruits was reported (Wells and 
Butterfield, 1997), as well as the growth of Escherichia coli O157:H7 in the wounds of apple (Janisiewicz et al., 1999). Fruit flies are easily contaminated externally and internally with E. coli, indicating the possibility of insect transmission of the bacterium (Janisiewicz et al., 1999). Presence of protozoa Giardia lamblia, Cryptosporidium parvum (Monge \& Chinchilla, 1996), Cyclospora cayetanensis and trematode Fasciola hepatica (Abdussalam et al., 1995) and others is also of concern; their occurrence on raw fruits is likely due to contact with animal and human faeces, untreated sewage and sludge from primary or secondary municipal water treatment facility. Nematode Caenorhabditis elegans can act as a vector to E. coli O157:H7, S. enterica and Listeria monocytogenes and might be a potential vector by shedding the pathogens for a considerable length of time (Anderson et al., 2006).

Human pathogenic bacteria might also be part of the bacterial association of plant phyllosphere, as a result of carry over by insects, wind, irrigation water, and survive to certain length of time (Beuchat, 1996). Enteropathogens can adapt to the phyllosphere environment, but may also be outcompeted by the epiphytic bacteria (Cooley et al., 2006).

The effect of growing technology applied might also have influence on the microbial contamination of fruits. It was noticed, that straw coverage during strawberry growing resulted in an increased microbial contamination (i.e. Enterobacteriaceae, moulds and yeasts, coliforms) of the berries under rainy weather conditions, but not in dry weather (Beczner \& Bata-Vidács, 2009).

Mould contamination might result in mycotoxin production. On apple, mainly during storage, Penicillium expansum produces mycotoxin patulin, which arises concern in apple juices and apple based baby foods (TaczmanBrückner et al., 2005). The main source of mould contamination of apples is the growing area; and the skin and tissue damages during harvesting, handling and transporting lead to the extensive proliferation and mycotoxin production of the mould during storage at low temperature $\left(\mathrm{cca} 10-15^{\circ} \mathrm{C}\right.$ ).

The ratio of plants from organic farming is increasing in the market following to environmental and customer demand. The organic and integrated systems had higher soil quality and potentially lower negative environmental impacts than conventional systems (Cassandro, 2008). The effect of organic production on the quality and safety of the plant foods is scrutinized, and there is an ongoing debate between pros and contras. Organic products have much lower amounts of pesticide residues compared to integrated or conventional ones (Baker et al., 2002), however, often criticised for having lower crop, and higher incidence of plant diseases, and greater spoilage during storage. Weibel and co-workers (1999) found, that organically grown apple fruits were firmer, had higher technical quality index, higher phosphorous, fibre and phenolic compounds content, and higher scores in the taste panel test. Postharvest quality was also investigated, and it was found, that the parameters determining storability are strongly influenced by the growing conditions (i.e. nutrient supply, watering and plant protection, etc.). Organically grown crops had slower growth rates and were physiologically more mature at harvest, and had longer storability, and due to their lower respiration rates and enzyme activity had lower storage losses (Lampkin, 1990). Róth and co-workers (2004) investigated four apple cultivars from organic and integrated productions in Hungary, concerning their -galactosidase and polygalacturonase enzyme activity, firmness and mass loss during storage. The statistical analysis of the data showed, that the effect of cultivar was the main factor in influencing the storability. Investigating the effect of growing area and production system (organic and integrated) on the storability (in air and CA conditions) and quality parameters of apple cv. Jonagold in Belgium, Róth and co-workers (2007) found, that storage conditions affected the quality of apples to a much greater degree, than the production system. Nagy and co-workers (2009a, b) and Holb and co-workers (2009) and Holb and Nagy (2009) concluded the same in their investigations.

The aim of this ongoing study was to compare the epiphytic microbiota of food safety concerns of apple as a function of cultivars, growing systems (organic and integrated), growing area and production year in Hungary.

\section{Materials and methods}

\section{Sampling}

At multiple time points throughout two growing seasons (2008-2009), fruits of Malus domestica cultivars were collected from two growing places (Újfehértó, Pallag) from integral and organic orchards (Table 1). Samples were collected by the staff in Újfehértó and Pallag, and transferred to CFRI, Budapest, and were stored in refrigerator (at $4-7{ }^{\circ} \mathrm{C}$ ) until investigated (generally up to $2-5$ days). Altogether 47 samples were investigated.

\section{Microbiological investigation}

The average surface of 5-10 fruits per cultivars were calculated by measuring the apple diameters, and the microbiological results were calculated as log colony forming unit per $\mathrm{cm}^{2}\left(\mathrm{cfu} / \mathrm{cm}^{2}\right.$, or $\left.\log \mathrm{N} \mathrm{cm}^{-2}\right)$. Microbial determinations were carried out using standard food microbiological methods. Five fruits of each cultivar were washed in $90 \mathrm{ml}$ physiological saline peptone water (pepton $1 \mathrm{~g}, \mathrm{NaCl} 9 \mathrm{~g}$ in $100 \mathrm{ml}$ water), and the . mesophylic aerobic total count (MSZ 3640/3-86), moulds and yeasts (MSZ ISO 7954: 1999), Pseudomonas spp. (MSZ 3640/7-80), coliforms (MSZ 3640/18-79) and Escherichia coli (MSZ 3640/19-79) were quantitatively determined on general or selective media. Another five apples were used for the determination of presence/absence of Listeria monocytogenes (MSZ EN ISO 112900:1998) and Salmonella spp. (MSZ EN ISO 6579:2002). 


\section{Statistics}

Frequency distribution of the contamination level was calculated. Principal component analysis (PCA) was used to group the samples according to their total aerobic bacterial, mould and yeast contaminations. After forming the groups, discriminant analysis was used to control the goodness of PCA.

\section{Results}

No Pseudomonas spp., Listeria spp. and Salmonella spp. were found on any of the samples investigated. The presence of coliforms was sporadic, and in each case when present, it was around the detection limit $\left(10 \mathrm{cfu} / \mathrm{cm}^{2}\right)$, and no E. coli was found on any of the samples. The dominant mesophylic aerobic bacterial count, the presence of moulds and yeasts were characteristic for the microbiota of apple surface, regardless to growing system, locality and production year.

The mesophylic aerobic total microbal contamination of the apple surfaces was between $10-10^{9} \mathrm{cell} / \mathrm{cm}^{2}$, the majority being between $10^{3}-10^{5}$ $\mathrm{cfu} / \mathrm{cm}^{2}$, with a Gauss-like distribution. The distribution of cell counts was even in case of organic growing, and varied within a wider range for integral growing (Table 1, Fig 1). The frequency distribution of mould counts on the apple surfaces was also Gausslike, being the majority of samples contaminated by $10^{3}-10^{5} \mathrm{cfu} / \mathrm{cm}^{2}$, with no difference between the organically and integrally grown samples (Table 1, Fig 2). The occurrence of yeast was similar in case of both growing systems, varying between $10^{1}$ and $10^{4} \mathrm{cfu} / \mathrm{cm}^{2}$ (Table 1, Fig 3).

Principal component analysis was used to group the apple samples according to their main microbial contamination (aerobic total bacterial, mould and yeast counts). The program ranked the apple samples into 7 groups (except for two samples), according to their microbial load (Fig 4).
Table 1. Microbial contamination of apple cultivars

\begin{tabular}{|c|c|c|c|c|c|c|c|}
\hline Cultivar & $\begin{array}{l}\text { Sample } \\
\text { number }\end{array}$ & $\begin{array}{l}\text { Production } \\
\text { system }\end{array}$ & Year & $\begin{array}{l}\text { Place of } \\
\text { growing }\end{array}$ & $\begin{array}{c}\text { Total } \\
\text { aerobic } \\
\text { count } \\
\left(\mathrm{cfu} \times \mathrm{cm}^{-2}\right) \\
\operatorname{lgN}\end{array}$ & $\begin{array}{c}\text { Mould } \\
\text { count } \\
\left(\mathrm{cfu} \times \mathrm{cm}^{-2}\right) \\
\operatorname{lgN}\end{array}$ & $\begin{array}{c}\text { Yeast } \\
\text { count } \\
\left(\begin{array}{c}\left.\text { cfu } \times \mathrm{cm}^{-2}\right) \\
\operatorname{lgN}\end{array}\right.\end{array}$ \\
\hline Gála Must & 1 & Integrated & 2008 & Pallag & 2.64 & 3.08 & 2.3 \\
\hline Gála Must & 2 & Organic & 2008 & Pallag & 3.97 & 2.94 & 0 \\
\hline Prima & 3 & Integrated & 2008 & Újfehértó & 5.67 & 3.25 & 0 \\
\hline Prima & 4 & Organic & 2008 & Újfehértó & 4.76 & 2.61 & 0 \\
\hline Gála & 5 & Organic & 2008 & Újfehértó & 4.47 & 3.43 & 2.8 \\
\hline Remo & 6 & Integrated & 2008 & Újfehértó & 3 & 3 & 2.43 \\
\hline Remo & 7 & Organic & 2008 & Újfehértó & 1.39 & 3.71 & 0 \\
\hline Topáz & 8 & Integrated & 2008 & Újfehértó & 5.38 & 4.79 & 2.53 \\
\hline Topáz & 9 & Organic & 2008 & Újfehértó & 5.2 & 3.89 & 2.44 \\
\hline Idared & 10 & Integrated & 2008 & Pallag & 5.32 & 3.64 & 3.64 \\
\hline Idared & 11 & Organic & 2008 & Pallag & 5.44 & 2.44 & 3.88 \\
\hline Remo & 12 & Integrated & 2008 & Pallag & 4.25 & 3.23 & 3.2 \\
\hline Remo & 13 & Organic & 2008 & Pallag & 4.38 & 4 & 2.71 \\
\hline Prima & 14 & Organic & 2009 & Újfehértó & 4.69 & 4.23 & 0 \\
\hline Prima & 15 & Integrated & 2009 & Újfehértó & 4.77 & 2.8 & 0 \\
\hline Releika & 16 & Organic & 2009 & Újfehértó & 4.11 & 2.81 & 0 \\
\hline Releika & 17 & Integrated & 2009 & Újfehértó & 3.38 & 2.44 & 0 \\
\hline Resi & 18 & Organic & 2009 & Újfehértó & 4.88 & 3.11 & 3.44 \\
\hline Resi & 19 & Integrated & 2009 & Újfehértó & 3.94 & 2.08 & 0 \\
\hline Remo & 20 & Organic & 2009 & Újfehértó & 4.76 & 2.84 & 1.84 \\
\hline Remo & 21 & Integrated & 2009 & Újfehértó & 3.86 & 2.08 & 0 \\
\hline Rubinola & 22 & Organic & 2009 & Újfehértó & 4.41 & 2.69 & 1.3 \\
\hline Rubinola & 23 & Integrated & 2009 & Újfehértó & 4 & 2.72 & 2 \\
\hline Rajka & 24 & Organic & 2009 & Újfehértó & 3.65 & 3.3 & 2.61 \\
\hline Rajka & 25 & Integrated & 2009 & Újfehértó & 3.44 & 3.44 & 2.44 \\
\hline Rewena & 26 & Organic & 2009 & Újfehértó & 3.6 & 4.23 & 3.53 \\
\hline Rewena & 27 & Integrated & 2009 & Újfehértó & 3 & 3.44 & 2.36 \\
\hline Topáz & 28 & Organic & 2009 & Újfehértó & 3.69 & 5.44 & 1.96 \\
\hline Topáz & 29 & Integrated & 2009 & Újfehértó & 3.43 & 3.11 & 2.17 \\
\hline Florina & 30 & Integrated & 2009 & Újfehértó & 2.46 & 2.79 & 1.99 \\
\hline Prima & 31 & Integrated & 2009 & Újfehértó & 2.3 & 2 & 1.2 \\
\hline Rebella & 32 & Integrated & 2009 & Újfehértó & 2.58 & 2 & 1.87 \\
\hline Prima & 33 & Organic & 2009 & Újfehértó & 2.8 & 1.9 & 2 \\
\hline Remo & 34 & Organic & 2009 & Újfehértó & 2.15 & 2 & 2.23 \\
\hline Gála & 35 & Integrated & 2009 & Újfehértó & 2.65 & 1.84 & 1.68 \\
\hline Remo & 36 & Integrated & 2009 & Újfehértó & 3.2 & 2.7 & 2 \\
\hline Rajka & 37 & Integrated & 2009 & Újfehértó & 3.23 & 2.62 & 2 \\
\hline Idared & 38 & Organic & 2009 & Újfehértó & 3.11 & 2.75 & 2.11 \\
\hline Florina & 39 & Integrated & 2009 & Újfehértó & 3.99 & 2.8 & 2.91 \\
\hline Idared & 40 & Integrated & 2009 & Újfehértó & 3.41 & 2.95 & 2.56 \\
\hline Rewena & 41 & Integrated & 2009 & Újfehértó & 3.28 & 3.15 & 2.48 \\
\hline Topáz & 42 & Integrated & 2009 & Újfehértó & 3.08 & 4.23 & 2.57 \\
\hline Remo & 43 & Integrated & 2009 & Újfehértó & 9.3 & 2.85 & 2.49 \\
\hline Remo & 44 & Organic & 2009 & Újfehértó & 3.45 & 2.74 & 2.34 \\
\hline Topáz & 45 & Organic & 2009 & Újfehértó & 3.46 & 2.99 & 2.21 \\
\hline Red Idared & 46 & Integrated & 2009 & Újfehértó & 3.46 & 2.98 & 1.95 \\
\hline Idared & 47 & Integrated & 2009 & Újfehértó & 3.25 & 2.93 & 2.83 \\
\hline
\end{tabular}



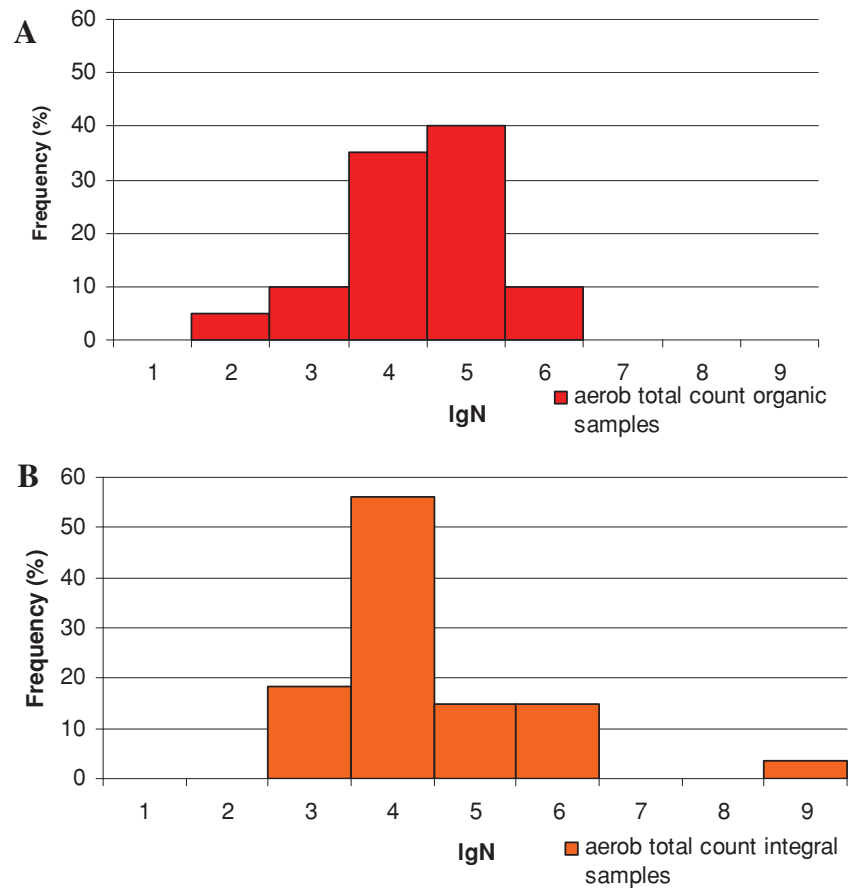

Figure 1. Frequency distribution of the surface aerobic total count contamination of apple from organic (A) and integrated (B) production
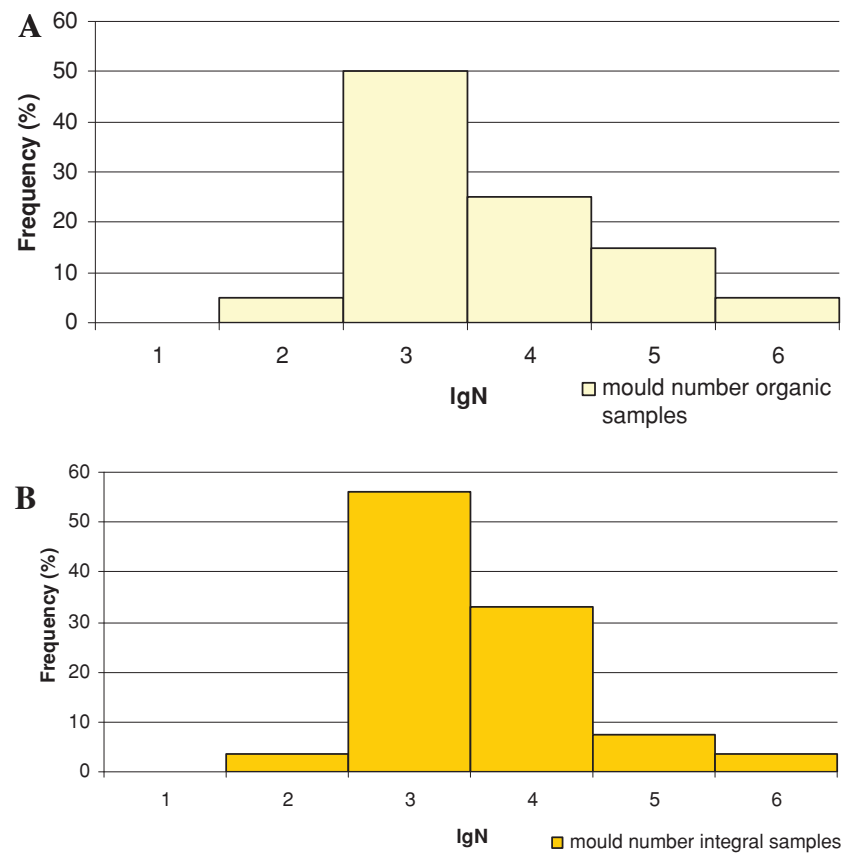

Figure 2. Frequency distribution of the surface mould contamination of apple from organic (A) and integral (B) production

In the group 1 (six samples) the contamination was low $\left(10^{2} / \mathrm{cm}^{2}\right.$ for aerobic total count, yeasts and moulds). Sample distribution between organic and integral growing is cca 50-50\%, and samples were mostly from 2009. Group 2 (four samples) had somewhat higher contamination, than group 1 $\left(10^{3} / \mathrm{cm}^{2}\right.$ for aerobic total count, yeasts and moulds), and $75 \%$ of the samples were from integral growing and all of them from year 2009. For group 3 (fourteen samples) contamination level of $10^{3} / \mathrm{cm}^{2}-10^{4} / \mathrm{cm}^{2}$ was characteristic for each microbial

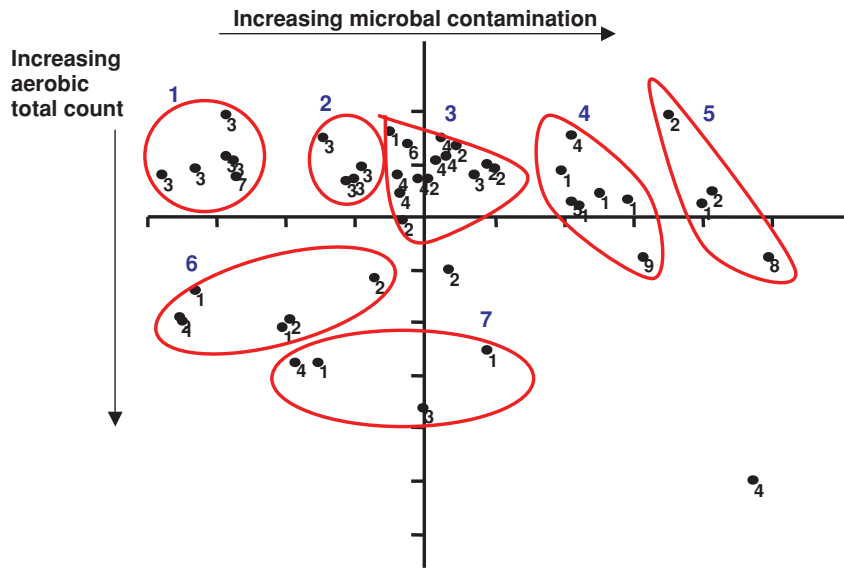

Figure 4. The principal component analysis (PCA) of apple cultivars of organic and integral production, on the basis of their microbial surface contamination (for decoding samples see Table)

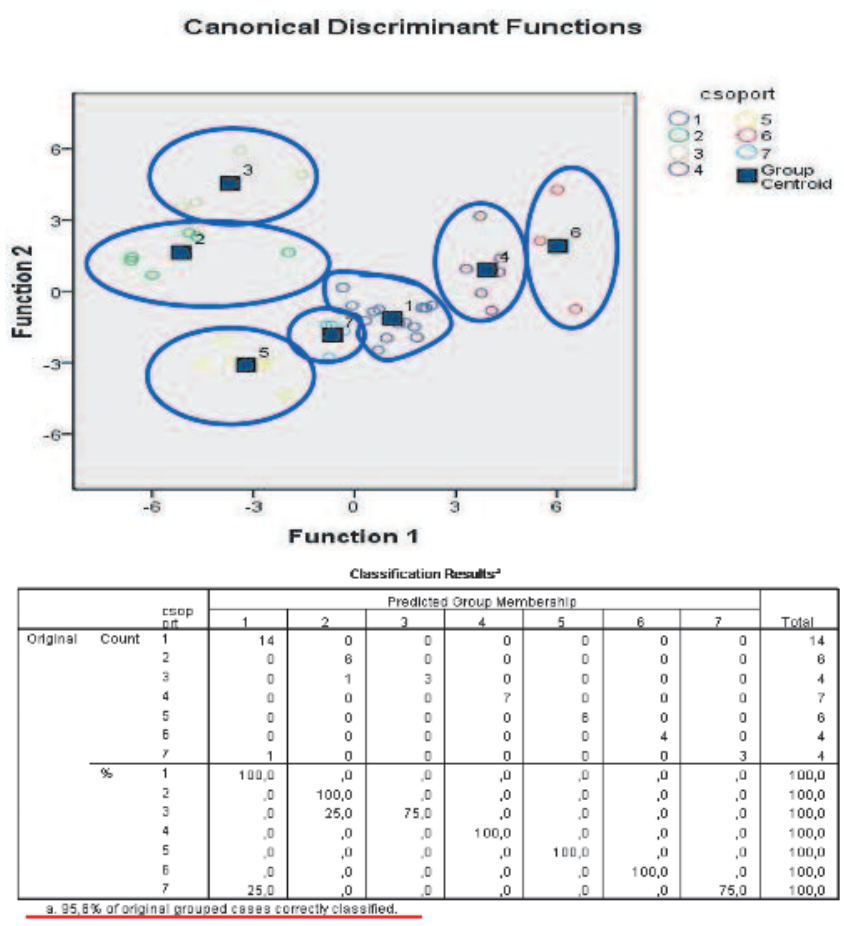

Figure 5. Discriminant analysis of apple samples (the goodness of PCA analysis)

groups, $80 \%$ of the samples were from integral growing and $80 \%$ from the year 2009. Group 4 (seven samples) had a contamination level of $10^{5} / \mathrm{cm}^{2}$ for aerobic total count, and $10^{3} / \mathrm{cm}^{2}$ for moulds and yeasts, and $70 \%$ of the samples were from organic system. Group 5 (four samples) had higher contamination level, than group 4 (aerobic total count $10^{5} / \mathrm{cm}^{2}$, moulds and yeasts $10^{4} / \mathrm{cm}^{2}$ ), $50 \%$ organic, year $2009-50 \%$ integral, year 2008. Group 6 (six samples) had a dominance of aerobic total count $\left(10^{4} / \mathrm{cm}^{2}\right)$, mould contamination was low $\left(10^{2} / \mathrm{cm}^{2}\right)$ and yeasts were totally absent. All samples were from year 2009, 50\%-50\% organic and integral growing. Group 7 (four samples) had high aerobic total count and moulds numbers $\left(10^{4}-10^{5} / \mathrm{cm}^{2}\right)$, yeasts were totally absent. All samples were cv. Prima, 50-50\% integral and organic growing. 
The PCA did not rank two samples (Remo 2009, Újfehértó, one organic and one integrated sample, harvested at different times) into any of the groups formed, having either extremely high aerobic total bacterial count (sample 43 ), or because of the combination of cell counts being different from the others (sample 20). Except for these two samples, the discriminant analysis proved the goodness of grouping (95.6\% level) (Fig 5). These results also show, in harmony with the distribution patterns of the microbial contamination, that there are no statistically detectable differences between the epiphytic microbial contamination of the apple fruits concerning the growing system, year and growing territory. No differences were found also among the cultivars.

\section{Acknowledgements}

The research was supported by NKTH OM-00045/08 project. The contribution to the laboratory work byx Éva Andrássy is gratefully acknowledged.

\section{References}

Abadias, M., Usuall, J., Anguera, M., Solsona, C. \& Vinas, I. (2008): Microbiological quality of fresh, minimally-processed fruit and vegetables, and sporuts from retail establishments. International Journal of Food Microbiology, 123: 121-129.

Abdussalam, M., Käferstein, M.F. \& Mott, K.E. (1995): Food safety measures for the control of trematode infections. Fd Control, 6: 71-79.

Anderson, G.L., Kenney, S.J., Millner, P.D., Beuchat, L.R. \& Williams, P.L. (2006): Shedding of foodborne pathogens by Caenorhabditis elegans in compost-amended and unamended soil. Fd. Microbiol., 23: 146-163.

Baker, B.P., Benbrook, C.M., Groth, E. \& Lutz Benbrook, K. (2002): Pesticide residues in conventional, integrated pest management (IPM)-grown and organic foods: insight from three US datasets. Food. Addit. Contam., 19: 427-446.

Beczner, J.\& Bata-Vidács, I. (2009): Microbiology of plant foods and related aspects. Acta Alimentaria, 38 (Suppl.): 99-115.

Beczner, J., Biró, B., Korbász, M. \& Jankó, Sz. (2004): A talaj, mint a növényi eredetü élelmiszerek mikrobás szennyezettségének forrása. (The soil as the source of microbial contamination of foods of plant origin.) Konzervújság, LII, 2004/3: 81-84.

Beuchat, L.R. (1996): Pathogenic microorganisms associated with fresh produce. J. Fd. Prot., 59: 204-216.

Beuchat, L.R. \& Ryu, J-H. (1997): Produce handling and processing p. Emerg. Inf. Dis., 3: 459-465.

Biró, B., Beczner, J., Németh, T., Azcon, R. \& Barea, J.M. (2008): Szennyvíziszapokkal bevitt, élelmiszerbiztonságot veszélyeztető és hasznos szimbionta mikrobák talaj- és dózisfüggő kolonizációja. Soil- and dose-dependent colonization of useful symbiontic microbes and that of food safety May, 28-29. Talajvédelem (Supplementum), 195-200.

Cassandro, V., T., Cristiano, A., S., Álvaro, L., M. \& Jackson, A., A. (2008): Yield and fruit quality of apple from conventional and organic production systems. Pesquisa Agropecuária Brasileira,. 43 (3): 333-340.

Cooley, M.B., Chao, D. \& Mandrell, R.E. (2006): Escherichia coli $\mathrm{O} 157: \mathrm{H} 7$ survival and growth on lettuce is altered by the presence of epiphytic bacteria. J. Fd Prot. 69: 2329-2335.

Janisiewicz, W.J., Conway, W.S., Brown, M.W., Sapers, G.M., Fratamico, P. \& Buchanan, L. (1999): Fate of Escherichia coli O157:H7 on fresh-cut apple tissue and its potential for transmission by fruit flies. Appl. environ. Microbiol.: 65, 1-5.

Holb, I.J., Gonda, I., Vagó, I., Nagy, P.T. (2009): Seasonal dynamics of nitrogen, phosphorus, and potassium contents of leaf and soil in environmental friendly apple orchards. Commun. Soil. Sci Plant Anal 40: 1-6: 694-705.

Holb, I.J., Nagy, P.T. (2009): Availability of calcium, magnesium, sulfur, copper, zinc, and manganese in the plant-soil system of integrated and organic apple orchards. Commun. Soil. Sci Plant Anal 40: (1-6): 682-693.

Lampkin, N. (Ed.) (1990): Organic farming. Farming Press Books, Ipswich, UK., 560-564.

Lund, B.M. \& Snowdon, A.L. (2000): Fresh and processed fruits. In: Lund, B.M. , Baird-Parker, T.C. \& Gould, G.W. (eds.): The microbiological safety and quality of food. Vol. I, Maryland, Aspen Publishers, 738-758.

Monge, R. \& Chinchilla, M. (1996): Presence of Cryptosporidium oocytsts in fresh vegetables. J. Fd Prot., 59: 202-203.

Nagy, P.T., Szabó, Z., Nyéki, J., Gonda, I. \& Holb, I. (2009a): Organic versus integrated apple growing: I. differences in soil and leaf parameters. Int. J. Horticult. Science 15 (4):57-60.

Nagy, P.T., Szabó, Z., Nyéki, J., Gonda, I. \& Holb, I. (2009b): Organic versus integrated apple growing: II. differences in fruit quality parameters. Int. J. Horticult. Science 15 (4): 61-63.

Nicholson, F.A., Groves, S.J. \& Chambers, B.J. (2005): Pathogen survival during livestock manure storage and following land application. Biores. Tech., 9: 135-143.

Róth, E., Berna, A., Beullens, K., Yarramrau, S., Lammertyn, J., Schenk, A. \& Nicolaï, B. (2007): Postharvest quality of integrated and organically produced apple fruit. Postharvest Biology and Technology, 45: 11-19.

Róth, E., Kovács, E. \& Felföldi, J. (2004): The effect of growing system on the storability of apple. Acta Alimentaria, 33 (1): 79-86.

Taczman-Brückner, A., Mohácsi-Farkas, Cs., Balla, Cs. \& Kiskó, G. (2005): Comparison of biocontrol activity of Kluyveromyces lactis with other yeast strains against Penicillium expansum. Acta Alimentaria, 34: 71-80.

Tyrrel, S.F. \& Quinton, J:N. (2003): Overland flow transport of pathogens from agricultural land receiving faecal wastes. J. appl. Microbiol., 94: 87S-93S.

Weibel, F.P., Bickel, R., Leuthold, S. \& Alföldi, T. (1999): Le mele di produzione biologica sono piu buone o piu salubri? (Are organically produced apples better or healthier?) Rivista Frutticoltura e Ortofloricoltura, 61 (5): 67-72.

Wells, J.M. \& Butterfield, J.E. (1997): Salmonella contaminatin associated with bacterial soft rot of fresh fruits and vegetables in the marketplace. Plant Disease, 81: 867-872.

Zhao, Y. (2005): Pathogens in fruit. In: Jongen, W. (ed.): Improving the safety of fresh fruit and vegetables. CRC Press, Boca Raton, Woodhead Publishing Ltd., Cambridge, 46-88. 